\title{
Stratifying, partially redrying and storing Douglas-fir seeds : effects on growth and physiology during germination *
}

\author{
Marlene DE MATOS MALAVASI, Susan G. STAFFORD \\ and D.P. LAVENDER \\ Department of Forest Science, \\ Oregon State University, Corvallis, OR 97331, U.S.A.
}

\begin{abstract}
Summary
Douglas-fir [Pseudotsuga menziesii (Mirb.) Franco] seeds collected from a coastal and an interior source in Oregon were stratified at $45 \mathrm{p} .100$ moisture content $(\mathrm{MC})$ and then redried (to 35 or 25 p. $100 \mathrm{MC}$ ) and/or stored (for 1 or 3 months) so that the complex interactions among stratification, redrying, and storage and their impacts on seed vigor and resultant seedling growth could be investigated. Stratified whole seeds and seed parts were hydrated to different degrees. Redrying stratified seeds to $35 \mathrm{p} .100 \mathrm{MC}$ did not affect $\mathrm{MC}$ of embryos or gametophytes, but redrying to 25 p. $100 \mathrm{MC}$ reduced $\mathrm{MC}$ of all seed structures. Three months of storage did not alter moisture distribution within seeds. Stratification reduced the germination percentage of interior-source seeds but hastened germination speed for seeds from both sources. Redrying stratified seeds to 35 and $25 \mathrm{p}$. $100 \mathrm{MC}$ increased seed vigor and secdling length and dry weight remarkably, a response similar to the 《invigorating effect» reported to improve seed performance for other types of plants. Storing stratified seeds, without redrying them, for 1 or 3 months generally reduced seed vigor, as reflected by germination speed and seedling length and dry weight, yet redried seeds stored no better than nondried. Levels of biochemical compounds studied were strongly correlated with germination speed. Results suggest that it would be advantageous to redry seeds to a range of 25 to 35 p. $100 \mathrm{MC}$ directly before sowing to produce vigorous seedlings or allow expression of stratification benefits.
\end{abstract}

\section{Introduction}

Stratification treatment (moist chilling) is a commonly used technique for overcoming dormancy in seeds of many temperate-zone species. However, practical problems arise in connection with storing stratified seeds when unfavorable weather during the sowing season makes it difficult to synchronize the end of stratification with the desired sowing date. In addition, preserving surplus stratified seeds creates a related problem because lengthening the stratification period may cause seed loss through pregermination or deterioration.

* F.R.L. 1895, Forest Research Laboratory, Oregon State University, Corvallis, OR 97331, 
Findings of workers studying redrying and storage of stratified forest-tree seeds have been inconsistent. BARNETT (1972) reported that stratified loblolly pine (Pinus taeda L.) seeds could be safely stored at 1 " $\mathrm{C}$ for 12 months after redrying to 10 p. 100 moisture content without reducing total germination percentage ; however, this procedure reinduced dormancy, necessitating restratification. Comparing germination of stratified Douglas-fir [Pseudotsuga menziesii (Mirb.) Franco] seeds redried for 3 weeks with that of nondried stratified and nonstratified seeds, HEDDERWICK (1968) noted that air drying did not adversely affect seed viability but, like BARNETr (1972), that the benefits of stratification were lost and seeds had to be restratified. In contrast, ALLEN (1962) found that even prolonged storage of stratified Douglasfir seeds redried to about 10 p. 100 moisture content rarely offset the stratification effect completely and had little if any effect upon germinative capacity where seed quality was high. VANESSE (1967) reported no adverse effect on seed viability of stratified Douglas-fir seeds redried to a moisture content below 7 p. 100 , noting that these seeds could be safely stored at $5^{\circ} \mathrm{C}$ for "several weeks " before sowing. DANIELSON \& TANAKA (1978) stratified, air dried, and stored (at 2 "C) seeds from ponderosa pine (Pinus ponderosa Dougl. ex Laws.) and Douglas-fir seed lots. The redried ponderosa pine seeds (moisture content of approximately $26 \mathrm{p}$. 100) could be stored for 9 months without losing their viability or stratification benefits; however, germination of the redried Douglas-fir seeds declined about 40 p. 100 , probably due to their higher moisture content (approximately $37 \mathrm{p}$. 100) during storage. Later, EDwands (1981) found that stratified Abies seeds redried to approximately 25 p. 100 moisture content could be stored for up to 12 months without losing their viability or the benefits of stratification and, further, that redrying stratified seeds stimulated germination to much higher levels than stratification alone.

We conducted the research reported here and in the companion paper (Stratifying, Redrying, and Storing Douglas-fir Seeds: Biochemical Responses, DE MAtos Malavasi et al., 1985) to study further the physiological effects of stratification on Douglas-fir seeds and the possible expression of those effects during germination. In this aspect of the study, we investigated the complex interactions among stratification and subsequent redrying and storage and their impacts on seed vigor and seedling growth. Further, because no published data relate moisture content of the whole seed to that of its parts (embryo, gametophyte tissue, seed coat), we examined those relationships as well. Gcrmination involves the physiology of living tissues in gametophyte and cmbryo; however, the seed coat, which makes up about 40 p. 100 of the seed weight, is essentially dead. To meaningfully relate moisture content to germination, then, requires that the moisture content of tissues involved in germination be known.

\section{Materials and Methods}

Two Douglas-fir seed lots with high germinative capacity were obtained from a commercial seed company. Seeds in both lots had been collected in 1980 in Oregon, one lot from coastal seed zone 061 (elevation $0-500 \mathrm{ft}$ ), the other from interior seed zone 252 (elevation 501-1000 ft). Seeds were stored for 4 months in airtight containers at $1{ }^{\circ} \mathrm{C}$, then, before experimentation, screened to obtain large, uniform size. Screened seeds of both lots [average moisture content (MC) of $7 \mathrm{p}, 100$ ] were stored at 1 " $\mathrm{C}$ over the 2-year duration of the experiment. 


\subsection{General procedure}

Seeds were soaked in water at room temperature for 24 hours, drained, placed in 4-mil polyethylene bags, and then stratified at $3{ }^{\circ} \mathrm{C}$ for 28 days at $45 \mathrm{p} .100 \mathrm{MC}$. $\mathrm{MC}$ of some stratified seeds was adjusted downward to 35 or $25 \mathrm{p} .100$ by redrying tseeds in a single layer on a mesh screen in a standard room $\left(21^{\circ} \mathrm{C}\right.$ temperature, 70 p. 100 relative humidity) for 20 minutes or 48 hours, respectively. Most redried ( 35 or 25 p. $100 \mathrm{MC}$ ) and nondried (45 p. $100 \mathrm{MC}$ ) seeds were then placed in dry 4-mil polyethylene bags and returned to cold storage at $3^{\circ} \mathrm{C}$ for 1 or 3 months; the rest were not stored. In total, seeds from the original sample $(7 \mathrm{p} .100 \mathrm{MC})$ and seeds at three MCs $(45,35$, and 25 p. 100), stored for two periods (1 and 3 months) or not stored at all, composed the 10 treatments (table 1), and effects of redrying and storage on whole seeds and seed parts, seed vigor, and seedling growth were assessed under the various treatment conditions.

\section{TABLE 1}

Treatment descriptions and corresponding experimental codes for Douglas-fir seeds from the two seed lots studied.

Descriptions des traitements et codification utilisée pour les deux lots de graines de Douglas étudiés.

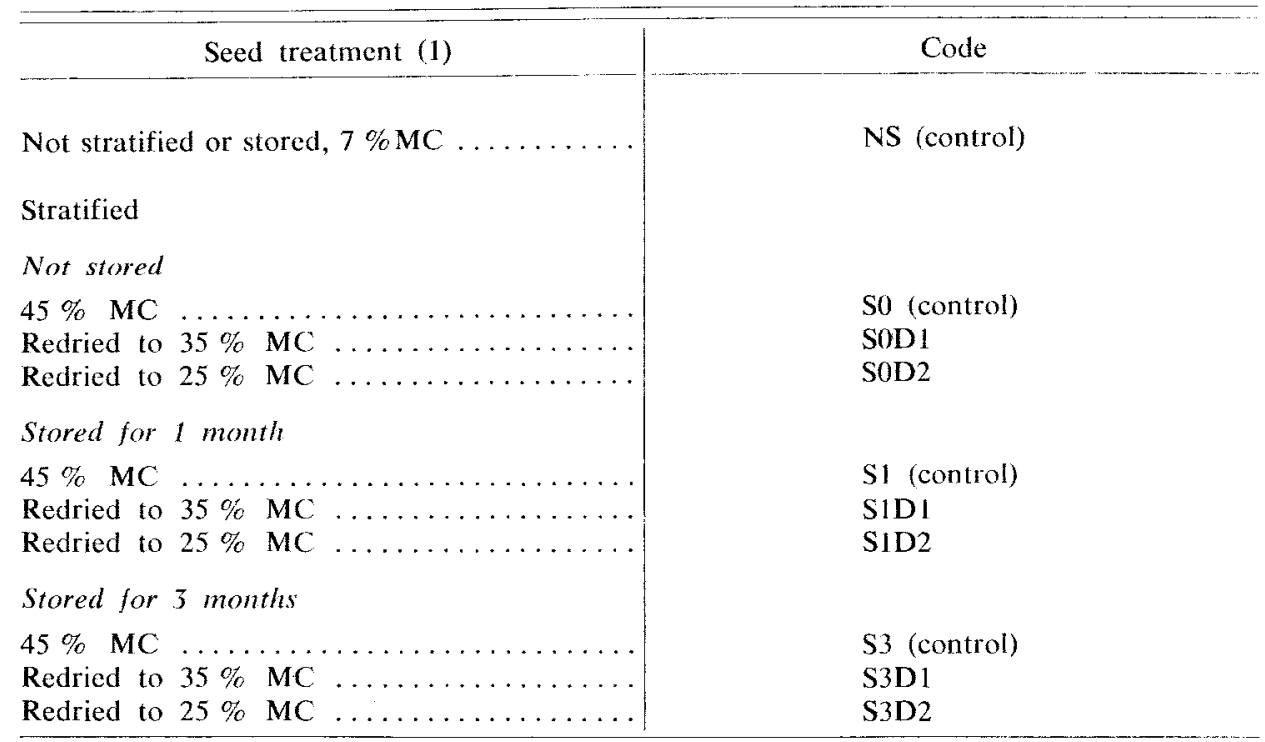

(1) $\mathrm{MC}=$ moisture content.

To attain the target MCs (35 or 25 p. 100) for redrying, 100 secds from each lot (10 replications of 10 seeds each) were air dried inside the standard room 
previously described (1) every 5 minutes up to 1 hour, (2) every $1 / 2$ hour up to 2 hours, (3) every hour up to 12 hours, and (4) every 12 hours up to 48 hours. Mean MC, expressed as a percentage of seed fresh weight, was calculated by ovendrying four samples of 10 seeds each for 24 hours at $105^{\circ} \mathrm{C}$ :

$$
\text { MC p. } 100=\frac{\text { fresh weight }- \text { dry weight }}{\text { fresh weight }} \times 100
$$

These means were used as the basis for determining how long seeds should dry to attain the target MCs.

The MC of seed parts-embryo, gametophyte tissue, and seed coat-was determined by dissecting four replications of 10 seeds of each of the nine stratification treatments inside a cold room $\left(3^{\circ} \mathrm{C}\right)$ at 90 p. 100 relative humidity. Nonstratified seeds (NS) were dissected inside a hot room $\left(33^{\circ} \mathrm{C}\right)$ at 32 p. 100 relative humidity. MC was again expressed as a percentage of fresh weight and calculated by the oven-drying method previously described.

Four hundred treated seeds (four replications of 100 seeds each) were germinated in clear, covered plastic dishes containing $200 \mathrm{ml}$ of sterilized peat moss and vermiculite and $15 \mathrm{ml}$ of water. Temperature alternated daily between $30^{\circ} \mathrm{C}$ for 8 hours and $20^{\circ} \mathrm{C}$ for 16 hours; illumination with cool-white fluorescent lights (1000 lux) accompanied the higher temperature period. Seeds were considered germinated when their radicles were at least $2 \mathrm{~mm}$ long. Germinants were counted every second day, up to 28 days. An index of seed vigor, expressed as germination speed, was then calculated :

Vigor $=\frac{\text { no. germinants (first count) }}{\text { index }}+\ldots+\frac{\text { no. germinants (last count) }}{\text { no. days to first count }}$

Length and dry weight of 40 seedlings (four replications of 10 secdlings each) from the germination test samples were recorded 5 days after radicles emerged. Length (in millimeters) was measured as seedling extension from the tip of the radicle to the top of the cotyledons, weight by oven-drying seedlings at $70^{\circ} \mathrm{C}$ until constant weight was attained.

Levels of certain biochemical compounds also were correlated with seed vigor and seedling growth. Because biochemical response was felt to be an intrinsic phenomenon, not a treatment-induced effect, we pooled all observations from the 10 treatments, two seed sources, and three replications, for a total of 60 . Growth analyses are presented here; details of the experimental methodology and results of the biochemical analyses are reported fully in the companion paper (DF MATos Malavasi et al., 1985).

\subsection{Statistical analysis}

Initially, analysis of variance for a completely randomized design was conducted on all data to assess significant treatment effects. Then t-tests were used to determine 
which treatment means were significantly different at the 5 p. 100 probability level $(\mathrm{P}<0.05)$.

Regressions were run on the biochemical data. Dependent variables for growth response - total germination (GERM), germination speed (SPEED), total germinant length (LENGTH), and germinant dry weight (DRWT) - were first regressed individually against the biochemical variables - adenosine triphosphate (ATP), total adenosine phosphates (TAP), deoxyribonucleic acid (DNA), ribonucleic acid (RNA), nucleotides (NUC), and energy charge (EC). Stepwise multiple regressions were then fitted for these same variables. DNA was the first variable entered for all dependent variables except GERM because it was the most highly correlated with almost all the dependent variables; for GERM, RNA was the first and only variable entered. Multiple regressions also were run on the data grouped by storage treatment. Canonical correlation, a multivariate analysis technique assessing the degree of relationship between two sets of variables (HARRIS, 1975), was used to determine any relationships between biochemical and growth variables not previously identified by regression.

\section{Results}

\subsection{MC of whole seeds and seed parts}

Each of the seed components hydrates to a different extent during stratification (table 2). MC of stratified whole seeds, seed coats, embryos, and gametophytes was, respectively, $7,13,11$, and 6 times greater than that of nonstratified whole seeds and seed parts.

Redrying stratified seeds from 45 to 35 p. $100 \mathrm{MC}$ did not alter MC of the embryo and gametophyte but significantly reduced that of the seed coat (table 3 ). On the other hand, redrying stratified seed from 45 to 25 p. $100 \mathrm{MC}$ significantly reduced $\mathrm{MC}$ in all seed structures.

TABLE 2

Mean (I standard error) moisture content (\%, fresh-weight basis) of nonstratified and stratified nondried whole seeds and seed parts (1).

Moyenne ( \pm erreur standard) du taux d'humidité (pourcentage exprimé par rapport au poids frais) de graines entières, et de lears différentes parties, avec ou sans stratification, sants séchage secondaire (1).

\begin{tabular}{l|c|c}
\hline & Nonstratified $7 \%$ MC) & $\begin{array}{c}\text { Stratified nondried } \\
(45 \% \text { MC) }\end{array}$ \\
\hline Whole seed $\ldots \ldots \ldots \ldots \ldots \ldots \ldots$ & $6.0( \pm 0.3) \mathrm{a}$ & $45.7( \pm 0.05) \mathrm{b}$ \\
Seed coat $\ldots \ldots \ldots \ldots \ldots \ldots \ldots$ & $4.2( \pm 0.2) \mathrm{a}$ & $55.5( \pm 0.8) \mathrm{b}$ \\
Embryo $\ldots \ldots \ldots \ldots \ldots$ & $4.7( \pm 0.4) \mathrm{a}$ & $51.8( \pm 1.6) \mathrm{b}$ \\
Gametophyte $\ldots \ldots \ldots \ldots \ldots \ldots$ & $5.7( \pm 0.3) \mathrm{a}$ & $35.0( \pm 2.4) \mathrm{b}$ \\
\hline
\end{tabular}

(1) Eight replications of 10 seeds each; means followed by the same letter within a row do not differ $(\mathrm{P}<0.05) ; \mathrm{MC}=$ moisture content. 
Generally, 3 months of storage did not affect MC of whole seeds or seed parts (table 4); the exception was seed coat MC in nondried stratified seeds stored for 3 months (S 3), which apparently was reduced.

\section{TABLE 3}

Mean ( \pm standard error) moisture content (\%, fresh-weight basis) of stratified whole seeds and seed parts, by moisture level (1).

Moyenne ( \pm erreur standard) du taux d'humidité

(pourcentage exprimé par rapport au poids frais) de graines entières, et de leurs différentes parties, après stratification avec ou sans séchage secondaire (1).

\begin{tabular}{|c|c|c|c|}
\hline & $45 \% \mathrm{MC}$ (nondried) & Redried to $35 \% \mathrm{MC}$ & Redried to $25 \% \mathrm{MC}$ \\
\hline Whole seed ...... & $45.7( \pm 0.5)$ & $35.8( \pm 0.7) b$ & $23.8( \pm 0.7) \mathrm{c}$ \\
\hline Seed coat $\ldots \ldots \ldots$. & $5.5(+0.8)$ al & $31.2( \pm 2.4) b$ & $18.7( \pm 0.8) \mathrm{c}$ \\
\hline Embryo ........ & $51.8( \pm 1.6) a$ & $51.7( \pm 2.4) \mathrm{a}$ & $32.3( \pm 2.0) b$ \\
\hline Gametophyte. & $35.0( \pm 2.4) \mathrm{a}$ & $35.7( \pm 0.9)$ a & $22.6( \pm 1.0) b$ \\
\hline
\end{tabular}

(1) Eight replications of 10 seeds each; means followed by the same letter within a row do not differ $(P<0.05) ; M C=$ moisture content.

\section{TABLE 4}

Mean ( \pm standard error) moisture content (\%, fresh-weight basis) of nonstored and stored stratified whole seeds and seed parts, by moisture level (1).

Moyenne ( \pm erreur standard) du taux d'humidité (pourcentage exprimé par rapport au poids frais) de graines entières, et de leurs différentes parties, après stratification, avec ou sans conservation, avec ou sans séchage secondaire (1).

-

$45 \% \mathrm{MC}$ (nondried)

Whole seed $\ldots \ldots \ldots \ldots \ldots \ldots \ldots$
Seed coat $\ldots \ldots \ldots \ldots \ldots \ldots \ldots$
Embryo $\ldots \ldots \ldots \ldots \ldots \ldots \ldots$
Gametophyte $\ldots \ldots \ldots \ldots \ldots \ldots$

Whole seed

Seed coat

Enbryo ...............

Gametophyte

Whole seed

Seed coat $\ldots \ldots \ldots \ldots \ldots \ldots$

Embryo ...............

Gametophyte

$$
\begin{aligned}
& 45.7( \pm 0.5) a \\
& 55.5( \pm 0.8) a \\
& 51.8( \pm 1.6) a \\
& 35.0( \pm 2.4) a
\end{aligned}
$$

\section{Redried to $35 \% \mathrm{MC}$}

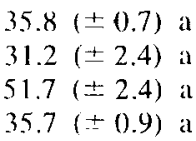

\section{Redried to $25 \% \mathrm{MC}$}

$$
\begin{aligned}
& 23.8( \pm 0.7) \mathrm{a} \\
& 18.7( \pm 0.8) \mathrm{a} \\
& 32.3( \pm 2.0) \mathrm{a} \\
& 22.6( \pm 1.0) \mathrm{a}
\end{aligned}
$$

(1) Eight replications of 10 seeds each; means followed by the same letter within a row do not differ $(\mathrm{P}<0.05) ; \mathrm{MC}=$ moisture content. 


\subsection{Growth response}

\subsection{Germination and seed vigor}

Germination percentages of the nondried stratified controls (S0, S1, S3) from both sources were significantly reduced by 3 months of storage (fig. $1 \mathrm{~A}, \mathrm{C}$ ). However. redrying stratified seeds generally did not affect germination percentages regardless of storage period. The exceptions were coastal-source seeds redried to 35 p. $100 \mathrm{MC}$ and stored for 1 month (S1D1), which had poorer germination, and interior-source seeds redried to 25 p. $100 \mathrm{MC}$ and stored for 3 months (S3D2), which had better germination, than the respective controls (S1, S3). Nonstratified controls (NS) had better germination than stratified controls (S0) for the interior source (fig. $1 \mathrm{C}$ ).

Seed vigor of nondried stratified controls (S0, S1, S3) from the coastal source (fig. $1 \mathrm{~B}$ ) progressively decreased as storage length increased, but that of interiorsource seed was reduced only by 3 months of storage (S3 ; fig. $1 \mathrm{D}$ ). However, average vigor significantly increased when nondried controls (S0) from the coastal source were redried to 35 p. $100 \mathrm{MC}$ (S0D1). Seeds from the interior source behaved similarly; in addition, redrying to 25 p. $100 \mathrm{MC}$ (SOD2) effectively increased seed vigor. For both sources, stratified seeds $(\mathrm{S} 0)$ were more vigorous than nonstratified (NS ; fig. $1 \mathrm{~B}, \mathrm{D}$ ).

\subsection{Seedling length and dry weight}

Seedlings produced from nondried stratified controls (S0, S1, S3) for both seed sources were progressively shorter as storage length increased (fig. $2 \mathrm{~A}, \mathrm{C}$ ). Seedlings originating from coastal-source seeds redried to 25 p. $100 \mathrm{MC}$ (S0D2, S1D2, S3D2) were significantly longer than controls at all storage periods; those redried to 35 p. $100 \mathrm{MC}$ and stored for 3 months (S3D1) also were longer than the controls (S3). Trends for seedlings from interior-source seeds were similar; however, seeds redried to 35 p. $100 \mathrm{MC}$ but not stored (SOD1) also produced seedlings longer than the controls (SO). Stratification alone did not affect seedling length for either seed source.

Seedlings grown from nondried controls that had been stored (S1, S3) werc significantly lighter than those grown from nonstored, nondried controls (S0) for the coastal source but not for the interior source (fig. $2 \mathrm{~B}, \mathrm{D}$ ). Seedling dry weight increased for seedlings grown from seeds redried to 25 p. $100 \mathrm{MC}$ (S0D2) for both sources (fig. $2 \mathrm{~B}, \mathrm{D}$ ). Coastal-source seedlings redried to 35 and $25 \mathrm{p} .100 \mathrm{MC}$ and stored for 1 month (S1D1, S1D2) were heavier than the controls (S1), but those redried to 35 p. $100 \mathrm{MC}$ and stored for 3 months (S3D1) were lighter than the controls (S3). Stratification alone did not affect seedling dry weight for either sced source.

\subsection{Biochemical responses}

SPEED correlated best with RNA $\left(\mathrm{r}^{2}=0.48\right)$ and ATP $\left(\mathrm{r}^{2}=0.49\right)$ in the simple regressions. These relativoly low $\mathrm{r}^{2}$ values may have resulted from the additional variation introduced by initially pooling treatments, seed sources, and replications. 


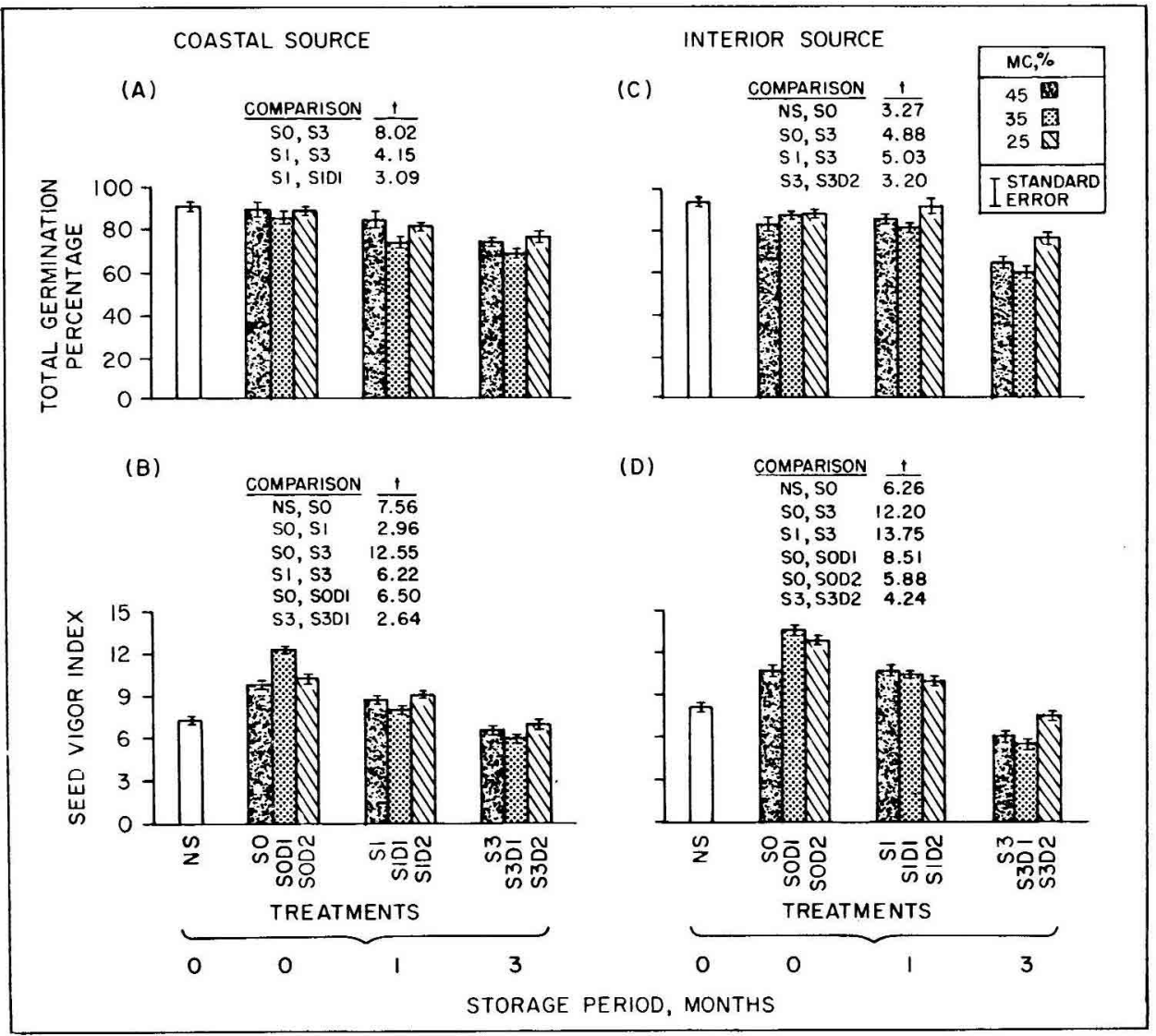

FIG. 1

Effects of redrying and storage on germination percentage and seed vigor of Douglas-fir seeds from the coastal $(A, B)$ and interior $(C, D)$ sources.

Each bar represents the mean of four replications of 100 seeds each; treatment differences, determined with t-tests, are significant at $\boldsymbol{P}<0.05$.

See table 1 for treatment-code explanations.

Effets du séchage secondaire et de la conservation sur le taux de germination et la vigueur des graines de Douglas de provenance côtière $(A, B)$ et de provenance intérieure $(C, D)$.

Chaque colonne représente les moyennes de quatre répétitions de 100 graines chacune; les différences entre traitements, déterminées par le test-t, sont significatives au seuil de probabilité $P<0,05$.

Voir tableau 1 pour l'explication des codes des traitements. 


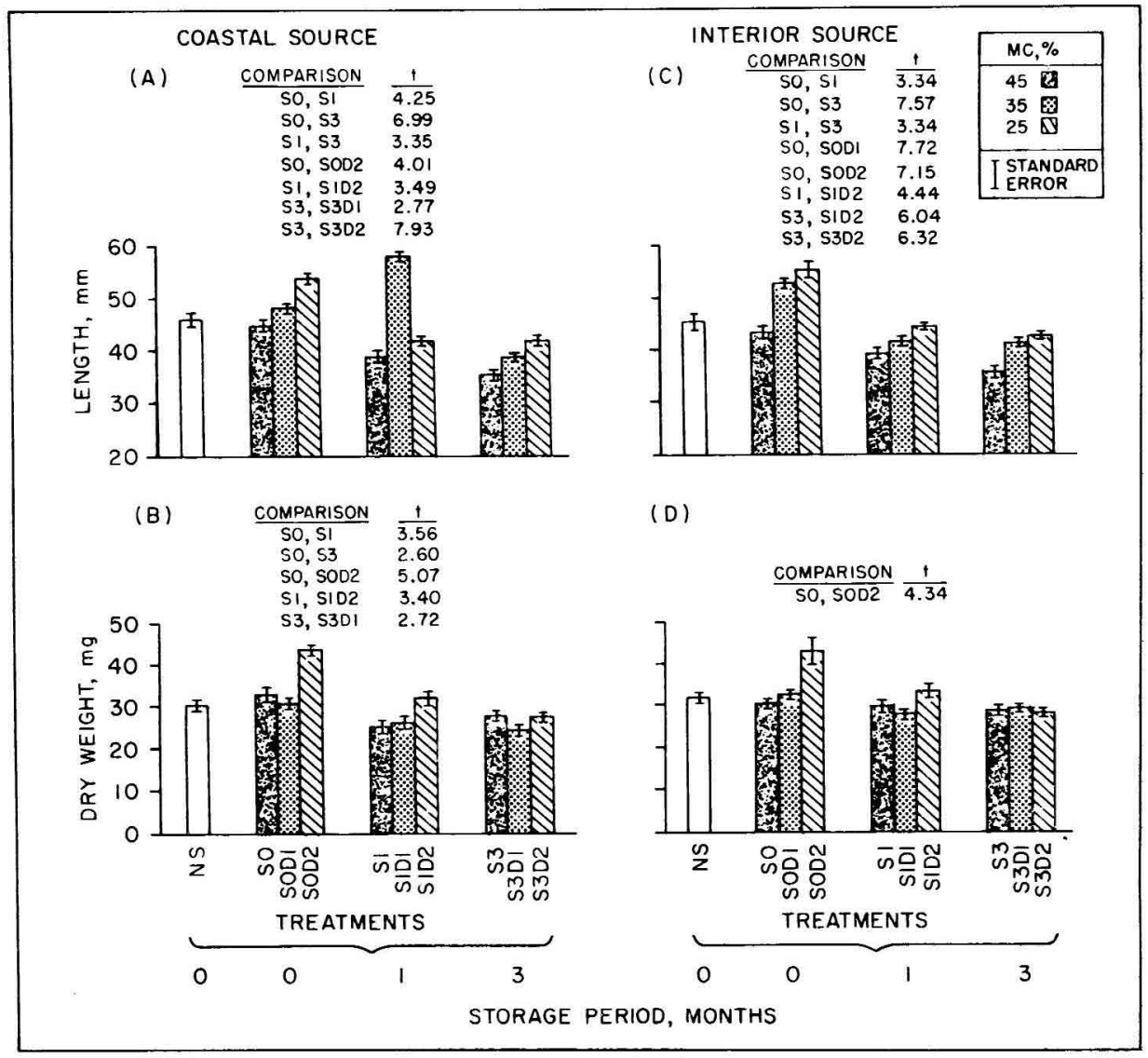

FIG. 2

Effects of redrying and storage on length and dry weight of 5-day-old seedlings grown from Douglas-fir seeds from the coastal $(A, B)$ and interior $(C, D)$ sources.

Each bar represents the mean of four replications of 10 seedlings each; treatment differences, determined with t-tests, are significant at $P<0.05$.

See table 1 for treatment-code explanations.

Effets du séchage secondaire et de la conservation sur la longueur et le poids sec de semis de Douglas âgés de 5 jours de provenance côtière $(A, B)$ et de provenancé intérieure $(C, D)$.

Chaque colonne représente les moyennes de quatre répétitions de 10 semis chacune; les différences entre traitements, déterminées par le test-t, sont significatives au seuil de probabilité $P<0,05$.

Voir tableau 1 pour l'explication des codes des traitements. 
Results of the multiple regressions were more valuable, not so much because of the higher $\mathrm{r}^{2}$ values but because of the consistent order in which the variables were entered into the models. SPEED and LENGTH were significantly correlated $\left(\mathrm{r}^{2}=\right.$ 0.69 and 0.64 respectively) with DNA, RNA, and ATP; no significant relationships were shown for GERM or DRWT. For data grouped by storage treatment, the strongest correlations were found for seeds that had not been stored. Of the four dependent variables, SPEED had the highest correlation $\left(r^{2}=0.91\right)$ with NUC, ATP, RNA, and DNA.

\section{TABLE 5}

Canonical analysis of growth variables versus biochemical variables $(1,2)$.

Analyse canonique des variables de croissance, en comparaison avec les variables biochimiques $(1,2)$.

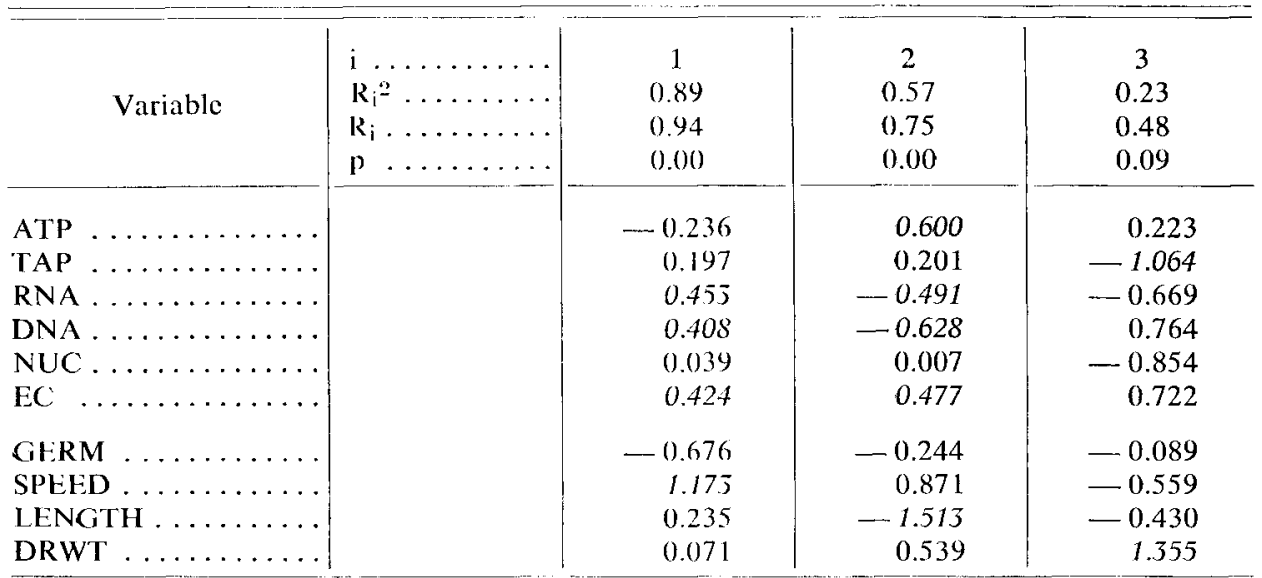

(1) Listing of canonical function coefficients with corresponding squared canonical correlations $\left(\mathrm{R}_{\mathrm{i}} 2\right)$, canonical correlations $\left(\mathrm{R}_{\mathrm{i}}\right)$, and significance levels $(\mathrm{p})$.

(2) Italicized coeflicients are those emphasized in the text in developing stobstantive interpretations of the canonical vatiates.

SPEED, LENGTH, and DRWT were each associated with a significant canonical correlation function (table 5). The fact that each of these three variables had a large coefficient on only one function suggests that they were not highly correlated among themselves. In the first function, SPEED was associated strongly (0.94) with RNA, DNA, and EC ; this combination of biochemical variables accounted for nearly 90 p. $100(0.89)$ of the total variation in the combination of growth variables measured. In the second function, LENGTH was associated $(0.75)$ with increasing nucleic acids (RNA, DNA) and decreasing energy variables (ATP, EC). Interestingly, the effect of ATP was somewhat balanced, or cancelled, by that of DNA $(0.600 \mathrm{vs}$. - 0.628), and the effect of EC by that of RNA (0.477 vs. -0.491$)$ (table 5). This combination of bicchemical variables accounted for 57 p. 100 of the variation in the combination of growth variables. In the third function, DRWT was associated $(0.48)$ 
with low TAP. Although significant (0.09), this relationship accounted for only 23 p. 100 of the variation between the two combinations of variables.

In all biochemical analyses, SPEED was the strongest dependent variable, correlating closely with both energy (EC, ATP) and genetic (DNA, RNA, NUC) variables. However, further evidence either for substrate accumulation or for intensified enzyme or system activity in stratified only and stratified, redried seeds is needed to explain why partial drying not only preserves the physiological effects of stratification but also enhances them.

\section{Discussion and Conclusions}

Stratification reduced the germinative percentage of interior-source sceds. According to LAVENDER (1978), such behavior commonly indicates one or more of the following conditions : seeds were not fully mature when cones were harvested and extracted; seeds were damaged during processing; or seeds deteriorated during storage. In this case, one or all these conditions could explain the reduced germination percentage of that seed lot because we had no control over seed handling procedures before purchase.

Yet stratification hastened germination speed in both seed lots, a result that supports the findings of ChING \& ChrNG (1973). However, unlike our study, Ching \& CHING found that stratification not only enhanced seed vigor but also significantly increased seedling length and dry weight. This disparity may have resulted because seedling length and weight were measured in an earlier developmental stage in our study than in ChIng \& CHing's. Different seed lots and years also may affect physiological responses.

Redrying seeds to 35 and 25 p. $100 \mathrm{MC}$ increased seed vigor and seedling length and dry weight remarkably; seeds from both sources may have benefited most from stratification when redried to less than $35 \mathrm{p}$. 100. The physiological responses observed here are similar to the «invigorating effect » reported to improve seed performance for grass, weed, crop, and woody species (HegarTy, 1978). In fact, several studies (Austin et al., 1969 ; Berrie \& Drennan, 1971; Hanson, 1973) have shown that presowing seed treatments in which seeds are fully or partially hydrated increase the rate, uniformity, and level of seed germination.

Storing nondried (45 p. $100 \mathrm{MC}$ ) seeds from both sources decreased germination percentage, seed vigor, and seedling length and dry weight, although coastal-source seeds were the more negatively affected. These results may be attributable to early cone collection; SORIENSEN (1980) found that stratification beyond about 30 days was detrimental to total germination and seedling size of early-collected Douglas-fir seeds. Yet redried seeds stored no better than nondried. Germination percentage, seed vigor, and seedling length declined significantly for both sources, and dry weight of seedlings grown from coastal-source seeds also was reduced. However, this lower germination percentage for stored, stratified seeds at all MCs may have been due to seed deterioration, rather than to reinduced dormancy; we found that most of the ungerminated seeds were not viable. But the data also suggest that redrying merely arrested, not reversed, the metabolic processes induced by stratification which often 
overcame seed dormancy and may initiate germination. There is no doubt that redrying substantially enhanced seed germination and growth, though the mechanisms of this effect are far from clear.

DANiELSON \& TANAKa (1978) reported that stratification effects, expressed as germination percentage and rate, were maintained when stratified Douglas-fir seeds were air dried and stored at $2{ }^{\circ} \mathrm{C}$; the increased germination rate due to stratification continued through 3 months of storage. Similar studies with ponderosa pine (DANIFLSON \& TANAKa, 1978) and Abies (EDwards, 1981) seeds revealed that stratified seeds not only can be dried and stored safely for a considerable period, but also that their germination rate and final germination percentage can be significantly increased. Our findings and DANIELSON \& TANAKA's (1978) for Douglas-fir may vary because of the different seed sources and years - ecotypic variations in physiological behavior have been observed in Douglas-fir seeds from different provenances (ALLEN, 1960) - or because of the prior history of the seeds tested - processing and storage methods may influence the degree of dormancy and, in turn, seed response to environmental manipulations. Further, the different mechanisms controlling dormancy in different species may explain why our results for Douglas-fir are dissimilar to those other workers for ponderosa pine and Abies.

Our study results make us skeptical about the advantages of reducing MC of stratified seeds to preserve stratification benefits through long storage periods. However, although storage negatively impacted stratified seeds from both sources regardless of $\mathrm{MC}$, the striking initial increase in seed vigor and scedling length and dry weight achieved by reducing MC of stratified seeds suggests that redrying such seeds directly belore sowing would be advantageous. However, further research is needed to elucidate the mechanism of this effect : we found that redrying whole seeds to 25 p. $100 \mathrm{MC}$ affected MC of the embryo and gametophyte tissue, whereas redrying to $35 \mathrm{p} .100 \mathrm{MC}$ affected $\mathrm{MC}$ of only the seed coat at the time of dissection (tables 3, 4). During storage and germination, a critical point may be reached at which both redrying treatments significantly increase synthesis of nucleic acids and germination speed. Although redrying treated seeds before continued storage does not result in more vigorous germination, redrying seeds before sowing does yicld more vigorous scedlings.

Reçu en février 1985.

Accepté en mai 1985.

\begin{abstract}
Résumé
Stratification, séchage secondaire et stockage des graines de Douglas : effets sur la croissance et sur la physiologie durant la germination
\end{abstract}

Des graines de Douglas [Pseudotsuga menziesii (Mirb.) Franco] issues d'une provenance côtière et d'une provenance intéricure ont été stratifićes, avec une teneur en cau (TE) de 45 p. 100 . puis re-sćchées soit à 35 p. 100 soit à 25 p. 100 de TE et étudiées directement ou après conscrvation (1 à 3 mois). L'objectif était l'étude des interactions complexes entre stratification, séchage et conservation, ainsi que leur impact sur la vigueur des graines et la croissance ultérieure des semis. Le degré d'hydratation des graines entières diffère de celui de leurs différentes parties. Le séchage de graines stratifiées jusqu'à 35 p. 100 de TE n'affecte pas la TE de l'embryon ni celle de l'endosperme, tandis qu'un re-séchage 
jusquà 25 p. 100 de TE réduit la TE de l'ensemble des éléments de la graine. Trois mois de conservation ne modifient pas la distribution de l'humidité à l'jntérieur des graines. In stratification réduit le taux de germination des graines de la provenance intérieure mais accélère la vitesse de germination pour les deux provenances. Un re-séchage des graines stratifiées, jusqu'à une TE de 35 p. 100 ou 25 p. 100 augmente de façon remarquable la vigueur des graines, la longueur des semis et leur poids sec, réponse comparable à l'«effet revigorant» rapporté comme une amélioration des performances des graines chez d'autres espèces. Une conservation de 1 à 3 mois des graines stratifiées, si clle n'est pas suivie d'un séchage réduit généralement la vigueur des graines, ce qui se répercute sur la vitesse de germination, la longueur des semis et leur poids sec. Cependant, les graines deshydratées ne se conservent pas mieux que celles qui ne le sont pas. Les niveatux des composés biochimiques étudiés sont fortement corrélés avec la vitesse de germination. Ces résultats suggèrent qu’il y aurait avantage à sécher les graines à 25 ou $35 \mathrm{p}$. 100 de TE, juste avant semis, pour produire des semis vigoureux et permettre l'expression des bénéfices apportés par la stratification.

\section{References}

ALLLN G.S., 1960. Factors affecting the viability and germination behavior of coniferous seed. IV. Stratification period and incubation temperature, Pseudotsuga menziesii (Mirb). Franco. For. Chron., 36, 18-29.

ALLEN G.S., 1962. Factors alfecting the viability and germination behavior of coniferous seed. VI. Siratification and subsequent treatment, Pseudotsuga menziesii (Mirb.) Franco. For. Chron., 38, 385-496.

Austin R.B., Langiden P.C., Hutchinson J., 1969. Some effects of «hardening 》 carrot secd. Ann. Bot., 33, 883-895.

BARNI:TT J.P., 1972. Drying and storing stratified loblolly pine seeds reinduces dormancy. Tree Planters' Notes, 23, 10-11.

Berrie A.M.M., Drennan D.S.H., 1971. The effect of hydration-dehydration on secd germination. New Plyytol., 70, 135-142.

Ching T.M., Ching K.K., 1973. Energy status in dormant and nondormant seeds. In : International Symposium on Dormancy in Trees, pp. 13-19, Pol. Acad. Sci.

Danizlson H.R., TanaKa Y., 1978. Drying and storing stratified ponderosa pine and Douglas-fir seeds. For. Sci., 24, 11-16.

Edwards D.G.W., 1981. A new prechilling method for true fir seeds. Proc. Intermoutain Nurseryman's Association and Western Forest Nursery Association. USDA For. Serv. Gen. Tech. Rep. INT-109. Intermoutain Forest and Range Experiment Station, Ogden, UT, 148 p.

Hanson A.D., 1973. The effects of inhibition-drying treatments on wheat seeds. New Phytol., 72, 1063-1073.

Harris R.J., 1975. A primer of multivariate statistics. Academic Prcss, New York, 332 p.

HedDerwick G.W., 1968. Prolonged drying of stratified Douglas-fir seeds affects laboratory germination. N. Z. For. Serv. Res. Leafl, 19, 2 p.

Hegarty T.W., 1978. The physiology of seed hydration and dehydration, and the relation betwcen water stress and the control of germination : a revicw. Plant, Cell and Environment, 1, 101-109.

LAVENDER D.P., 1978. Seed collection, handling, and damage. In : Regenerating Oregon's Forests, pp. 47-62, Cleary B.D. et al. Ed., Oregon State Univ. Extension Serv., Corvallis.

SORENSEN F.C., 1980. Effect of date of cone collection and stratification period on germination and growth of Douglas-fir (Pseudotsuga menziesii) seeds and seedlings. USDA For. Serv. Res. Note No. PNW-346, 11 p.

SrILES I.E., 1948. Relation of water to the germination of corn and cotton seeds. Plant Physiol., 23, 201-222.

Stone E.C., 1957. Embryo dormancy of Pinus Jeffreyi Murr. seed as affccted by temperature, water uptake, stratification, and seed coat. Plant Physiol., 32, 93-99.

Vanesse R., 1967. Influence du séchage secondaire des gaines de Pseudotsuga menziesii (Mirb.) Franco sur leur germination à $25^{\circ} \mathrm{C}$. Bull. Rech. agron. Gembloux, 2, 551-568. 